\title{
PARTISIPASI PEMERINTAHAN ADAT SERTA MASYARAKAT TENGANAN PEGRINGSINGAN DALAM PENGELOLAAN KEUANGAN DESA
}

\section{Dewa Ayu Putri Wirantari}

\author{
Universitas Udayana
}

putriwirantari@unud.ac.id

Received: 27 November 2019 | Reviewed: 29 December 2019 | Accepted: 20 January 2020

\begin{abstract}
ABSTRAK
Partisipasi pemerintahan adat di Desa Tenganan Pegringsingan dalam pengelolaan keuangan desa dilakukan melalui pemanfaatan serta pengelolaan ekowisata Desa sebagai mana pengelolaan ekowisata termasuk dalam pembangunan pariwisata yang menjadi salah satu bagian terpenting dalam perekonomian partisipasi pemerintah desa dalam pengelolaan dana desa mampu meningkatkan kesejahteraan masyarakat desa dan pemerataan pembangunan yang dilaksanakan melalui desa, Pengelolaan keuangan desa menjadi hak serta kewajiban Desa dalam penyelenggaraan pemerintahan desa yang dinilai bahwa sebagai bentuk kekayaan lain yang berhubungan dengan hak dan kewajiban desa dalam pengelolaan keuangan Desa. Dalam partisipasi pemerintahan adat di Desa Tenganan Pegringsingan bertujuan untuk pembangunan, pemberdayaan masyarakat serta dalam meningkatkan pengembangan jaringan ekowisata desa dalam pengelolaan keuangan. Pentinganya penelitian ini untuk mengetahui seberapa besar partisipasi pemerintah adat serta masyarakat adat dalam pengelolaan keuangan melalui ekowisata desa bentuk partispasi masyarakat dalam perekonomian di Desa Adat Tenganan dengan membuka usaha-usaha kecil di lingkungan Desa Tenganan Pegringsingan. Masyarakat sangat berperan penting dalam pengelolaan keuangan sebagai pengembangan Kawasan berbasis lokal wisdom. Metode penelitian yang digunakan adalah metode penelitian kualitatif adalah penelitian dengan pendekatan deskriptif, yang dimaksudkan sebagai pengukuran fenomena sosial tertentu yang mampu mengembangkan konsep serta menghimpun fakta tetapi tidak melakukan hipotesis
\end{abstract}

Kata Kunci : Partisipasi Masyarakat, Keuangan Desa, Pengelolaan Keuangan Desa

Korespondensi:

Universitas Udayana

Jalan PB Sudirman, Denpasar - Bali

E-mail: putriwirantari@unud.ac.id 


\begin{abstract}
The participation of customary government in Tenganan Pegringsingan Village in village financial management is carried out through the utilization and management of Village ecotourism, where ecotourism management is included in tourism development which is one of the most important parts in the economy. implemented through the village, Village financial management becomes the rights and obligations of the Village in the administration of village government which is considered as another form of wealth that is related to the rights and obligations of the village in the management of Village finances. In the participation of traditional government in the village of Tenganan Pegringsingan aims for development, community empowerment and in increasing the development of the village ecotourism network in financial management. The importance of this research is to find out how much the participation of indigenous governments and indigenous peoples in financial management through village ecotourism is a form of community participation in the economy in Adat Tenganan Village by opening small businesses in the village of Tenganan Pegringsingan. The community plays an important role in financial management as the development of local wisdom-based zones. The research method used is a qualitative research method is research with a descriptive approach, which is intended as a measurement of certain social phenomena that are able to develop concepts and collect facts but do not make hypotheses
\end{abstract}

Keywords: Community Participation, Village Finance, Village Financial Management

\title{
PENDAHULUAN
}

Pengembangan pariwisata di daerah Tenganan tidak luput dari Pembangunan kepariwisataan oleh pemerintah daerah kabupaten Karangasem, dalam perencanaan pengembangan destinasi wisata sebagai salah satu cara yang dilakukan pemerintah daerah dalam menarik perhatian para wisatawan baik lokal maupun internasional, pembangunan pariwisata mendongkrak dan mampu menghidupkan sektor usaha sebagai sarana akomodasi, sektor kepariwisataan merupakan salah satu penyumbang terbesar dalam perekonomian, pada tahun 2004-2008 industri pariwisata telah terbukti dalam menkontribusi yang sangat signifikan dalam pembangunan ekonomi nasional Sunaryo(2013), peningkatan ekonomi juga mempengaruhi peningkatan kesejahteraan dan pemberdayaan masyarakat yang berpotensi dalam meningkatkan kualitas kehidupan masyarakat lokal yang berada pada daerah wisata. sebagai kawasan pariwisata, daerah yang memiliki perkembangan pariwisata mempunyai tantangan dalam penyerapan tenaga kerjanya yang dituntut memiliki skill yang menunjang industri pariwisata khusus nya daerah yang dijadikan Desa Wisata. 
Pengelolaan keuangan desa keikutsertaan masyarakat dalam proses pengidentifikasian masalah dan potensi yang ada di masyarakat, serta pemilihan dan pengambilan keputusan tentang alternatife solusi untuk menangani masalah keuangan desa, sebagai upaya mengatasi masalah, dan keterlibatan masyarakat dalam proses mengevaluasi perubahan yang terjadi menjadi hal yang sangat penting dalam suatu daerah, partispasi masyarakat Tenganan dalam pengelolaan keuangan desa mengacu pada satu program, selain memberikan pengaruh dalam keuangan desa juga memberikan pengaruh dalam pembangunan suatu Desa. Pembangunan desa adalah perpaduan yang serasi antara kegiatan partisipasi masyarakat dalam pihak dan kegiatan pemerintah di satu pihak. Bahwa pada hakekatnya pembangunan desa dilakukan oleh masyrakat itu sendiri. Sedangkan pemerintah memberikan bimbingan, bantuan, pembinaan, dan pengawasan. Pembangunan di desa dapat menyentuh seluruh lapisan masyarakat maka harus diterapkan prinsipprinsip pembangunan, sasaran pembangunan dan ruang lingkup pembangunannya.

Pengelolaan keuangan desa dikembangakan untuk meningkatkan pariwisata, dimana banyaknya potensi yang dapat dipertontonkan kepada wisatawan lokal dan wisatawan asing, seiring dengan perkembangan jaman maka perkembangan pariwisata juga semakin maju, Perkembangan pariwisata yang dimiliki oleh Desa Adat Tenganan Pegringsingan, atas hasil musyawarah dengan beberapa tokoh pemuda dan tokoh-tokoh adat serta kelompok masyarakat yang memiliki wawasan luas sehingga disepakitilah adanya program yang bisa diolah oleh masyarakat yang mampu dimanfaatkan oleh masyarakat dan kembali ke masyarakat dari sektor agraris menjadi sektor jasa khususnya jasa pariwisata. Desa Tenganan Pegringsingan sebagai objek wisata sekaligus sebagai Bali Aga, dimanan secara tatanan kehidupan masyarakatnya masih menjunjung kearifan lokal, yang memiliki adat istiadat sangat kental dengan warisan budaya yang mampu menjaga dengan baik serta mempertahankan tradisional tanpa terpengaruh pada budaya luar. 
Peningkatan ekonomi mempengaruhi peningkatan kesejahteraan dan pemberdayaan masyarakat yang berpotensi dalam meningkatkan kualitas kehidupan masyarakat lokal yang berada pada daerah wisata. sebagai kawasan pariwisata, daerah yang memiliki perkembangan pariwisata mempunyai tantangan dalam penyerapan tenaga kerjanya yang dituntut memiliki skill yang menunjang industri pariwisata khusus nya daerah yang dijadikan Desa Wisata, dalam pengembangan objek wisata di Desa Tenganan Pegringsingan. Pengelolan Keuangan memiliki manfaat sebagai terciptanya model-model pengembangan pariwisata khususnya desa wisata yang masyarakatnya dapat melestarikan potensi alam dan sosial budayanya berdasarkan kearifan lokal, serta mampu menunjang keuangan desa adat dalam membangun desa yang mandiri dan mampu mengelola keuangan Desa. Pemerintah desa memiliki hak dalam menyusun perencanaan pembangunan desa yang sesuai dengan kewenangan yang mengacu pada perencanaan pembangunan desa. Pengelolaan keuangan dana desa dapat diuraikan sebagai berikut:

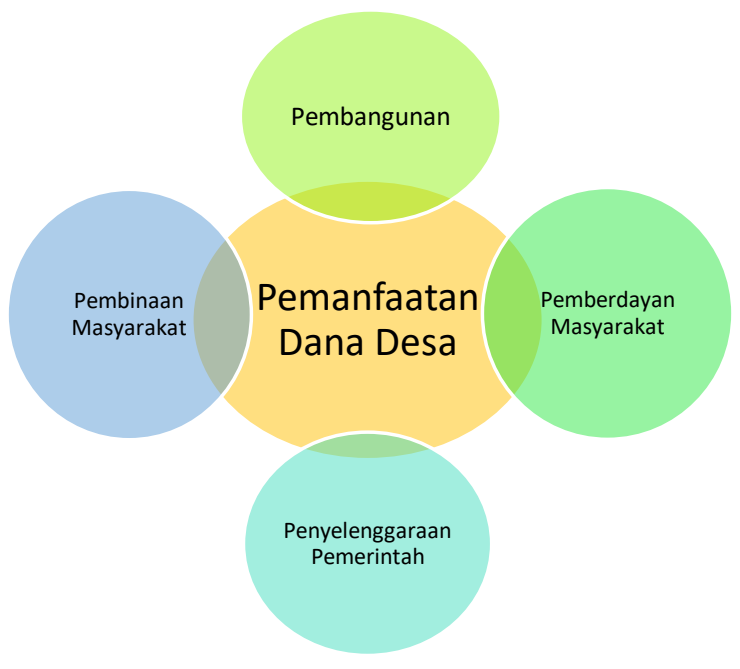

\section{Diagram 1. Pemanfaatan Keuangan Dana Desa}

Sumber : Hasil Penelitian Penulis

Pengelolaan dan pemanfaatan dana desa memiliki visi diantaranya dalam pembangunan, pemberdayaan masyarakat, penyelenggaraan pemerintah, serta pembinaan masyarakat. Beberapa hal dalam pemanfaatan dana Desa menjadi hal yang sangat penting terutama dalam pemberdayaan 
masyarakat dalam wujud partisipasi, Desa Tengenan Pegringsingan memberdayakan masyarakat melalui Tenun, Telur serta lontar yang dimanfaatkan sebagai sumber penunjang pariwisata di Desa Tenganan Pegringsingan. Desa Adat Tenganan Pengringsingan serta Nusa Ceningan ,(Bevaola:2015) menyatakan bahwa JED sendiri merupakan jaringan ekowisata yang bekerjasama dengan salah satu LSM lingkungan tertua di Bali yaitu yayasan wisnu. Adapun tujuan yang ingin dicapai melalui JED ialah (a) Menumbuhkan kesadaran masyarakat desa dalam mengelola berbagai sumberdaya yang mereka punya serta melestarikan kearifan lokal, (b) JED yang dibuat untuk dan oleh masyarakat, dan keuntungan yang diperoleh akan diperdayakan kembali untuk masyarakat serta konservasi desa-desa.

Konsep JED mengembalikan esensi model bisnis pariwisata yang berbasis masyarakat, melaui JED wisatawan yang berkunjung ke Tenganan Pengringsingan akan didampingi secara langsung, sekitar $60 \%$ biaya yang dipatok akan dikontribusikan untuk desa sisanya akan dikelola secara operasional, dana yang berhasil dihimpun melalui JED yang sementara bisa dibukukan bersihnya sebesar Rp 50 juta yang dikurangi dengan biaya manajemen serta pelatihan pada setiap desa akan memperoleh secara deviden Rp3-4 juta (Dandhy:2016) JED melakukan koordinasi dengan masyarakat desa dengan menawarkan jasa pariwisata dengan mengadopsi sistem koperasi dengan melakukan sistem pembagian deviden setiap tahunnya dengan proses bahwa wisatawan membayar langsung ke JED kemudian JED membayarkannya ke Desa. Jaringan Ekowisata Desa (JED) memiliki manfaat sebagai terciptanya model-model pengembangan pariwisata khususnya desa wisata yang masyarakatnya dapat melestarikan potensi alam dan sosial budayanya brdasarkan kearifan lokal, serta mampu menunjang keuangan desa adat dalam membangun desa yang mandiri. Berdasarkan latar belakang tersebut, yang menjadi rumusan masalah dalam penelitian ini adalah:

Bagaimana Pengaruh Pemerintah Desa Adat dan Masyarakat Adat Tenganan Pegringsingan dalam pengelolaan keuangan desa melalui peningkatan Jaringan Ekowisata Desa?

Adapun tujuan yang ingin dicapai yaitu untuk mengetahui sumber keuangan dari Desa Adat Tenganan, serta peran masyarakat desa adat Tenganan terhadap keberlangsungan pariwisata di Desa Tenganan dan pengelolaan keuangan desa yang mampu menumbuhkan kesadaran masyarakat desa dalam mengelola berbagai sumber daya yang mereka punya. Pengelolaan keuangan desa adat yang memiliki objek wisata. Dan dapat sebagai rujukan bagi pemerintah desa dalam peningkatan pengelolaan keuangan desa. 


\section{KAJIAN TEORI}

\section{Teori Partisipasi}

Partisipasi sebagai bentuk interaksi yang dilakukan oleh masyarakat ataupun pemerintah dalam melakukan keputusan atau dalam proses pengambilan keputusan. Kesediaan dalam bertanggung jawab sebagai elemen yang tidak mampu dipisahkan dari pengertian partisipasi (Sutarto,1980). Menurut pendapat Sastropoetro (1996) menyatakan sebagai tolak ukur keberhasilan suatu partisipasi ialah (a). melalui pertisipasi hasil kerja yang dicapai semakin meningkat, (b). Partisipasi pelayanan atau service mampu memberikan biaya murah (c). Partisipipasi memiliki nilai dasar yang sangat berarti dalam meningkatkan kualitas SDM. (d). partispasi sebagai katalisator dalam pembangunan (e). partispasi menimbulakan rasa tanggung jawab (f) Partispasi menjamin bahwa pekerjaan dilaksanakan kearah yang benar, (g). terdapat kesadaran yang ditimbulkan dalam berpartisipasi terutama dalam usaha serta permasalahan yang dihadapi. Partisipasi desa adat menjadi sangat penting dalam pemerintahan adat berdasarkan pemaparan Soekamto (2004:212) partisipasi sebagai aspek dinamis dari kedudukan masyarakat atau organisasi yang berada dalam pelayanan publik, seseorang melakukan hak serta kewajiban harus sesuai dengan kedudukannya dan harus menjalankan suatu peran, kedudukan dan peran tidak dapat dipisahkan karena kedua hal tersebut menjadi hal yang paling penting dalam suatu organisasi pemerintahan, baik pemerintah adat, dan pemerintah daerah. Peranan sebagai aspek dinamis yang dilakukan oleh seseorang dalam memangku suatu posisi sehingga dapat melakukan hak-hak dan kewajiban sesuai dengan kedudukannya. Henry Mintzberg dalam Thoha (2003:264-274) menyatakan terdapat peranan yang paling penting yang harus dilakukan oleh pemimpin suatu pemerintahan adat atau pemerintah daerah diantaranya:

a. Peranan Hubungan Antar Pribadi (Interpersonal Role) adalah Peranan sebagai Tokoh (Figurehead), dimana suatu peranan yang dilakukan dapat mewakili organisasi.

b. Peranan sebagai pejabat perantara (Liaison Manager), pemimpin dapat berperan atau berinteraksi dengan orang yang berada di luar organisasinya, sehingga mendapatkan informasi. 


\section{Kebijakan Pariwisata}

Goeldner dan Ritchie (2006) menjabarkan kebijakan pariwisata sebagai peraturan yang dapat memberikan kerangka dalam pengambilan keputusan individu maupun organisasi yang mempengaruhi pengembangan serta pembangunan pariwisata dalam jangka panjang. Biederman(2007) menyatakan kebijakan pariwisata merupakan peningkatan kemajuan negara atau daerah yang digunakan dalam pembangunan,Muljadi (2009), menyatakan bentuk-bentuk pariwisata dikenal oleh masyarakat umum, antara lain : a.Cultural tourism adalah etnis perjalanan wisata yang mampu memotivasi dikarenakan adanya daya tarik berdasarkan seni atau budaya daerah, b.Recuperational tourism adalah perjalanan wisata yang dapat memotivasi sebagai menyembuhkan penyakit, dan memberikan pelayanan, c.Commercial tourism perjalanan wisata yang dapat memotivasi dalam melakukan perjalanan berkaitan dengan perdagangan nasional atau internasional misalnya dalam penyelenggaraan expo, fair, dan jenis lainnya, d.Polotical Tourism adalah perjalanan pariwisata yang dilakukan sebagai tujuan yang berhubungan dengan kegiatan suatu negara.

\section{Pemerintahan Desa dalam Pengelolaan Keuangan Daerah}

Berdasarkan Permendagri RI Nomor 113 tahun 2014 menyatakan bahwa Pemerintah Desa sebagai penyelenggaraan urusan pemerintahan dari tingkat paling bawah sebagaimana mengurus kepentingan masyarakat setempat pemerintahan desa dibentuk oleh sekelompok masyarakat desa yang melakukan pememilihan beberapa orang anggota masyarakat desa yang dipercaya dan dapat mengatur, serta menata, melayani, kepentingan kelompok masyarakat desa. (Widjaja:2002) menyatakan pemerintahan desa merupakan kegiatan pemerintahan yang dilaksanakan secara Bersama-sama oleh pemerintahan desa yang terdiri dari Kepala Desa serta Perangkat Desa, Pemerintahan desa diselenggarakan oleh pemerintah desa yang memiliki kewenangan desa di bidang penyelenggaraan pemerintahan desa, pelaksanaan pembangunan desa, pembinaan kemasyarakatan desa, dan pemberdayaan masyarakat desa.

(Widjaja:2002) menyatakan bahwa kerangka sistem penyelenggaraan pemerintahan terlihat sebagai sistem pengelolaan keuangan pada dasarnya merupakan subsistem dari sistem pemerintahan yang dikelola oleh daerah tersebut. Berdasarkan Undang-Undang No. 22 Tahun 1999 dan Undang-Undang No. 25 Tahun 1999 pemerintah pusat dan Daerah adalah satu kesatuan yang tidak dapat dipisahkan sebagai upaya dalam penyelenggaraan pemerintahan dan pemayanan 
kepada masyarakat. Tujuan dari kedua Undang-Undang tersebut bukan hanya pada keinginan dalam melimpahkan kewenangan dan pembiayaan dari pemerintah pusat ke pemerintahan daerah, tetapi lebih sebagai peningkatan serta efisiensi dalam pengelolaan sumber keuangan daerah dalam rangka peningkatan kesejahteraan dan pelayanan kepada masyarakat.

\section{METODE PENELITIAN}

\section{Desain Penelitian}

Metode penelitian yang digunakan dalam penelitian ini adalah penelitian kualitatif Singarimbun dan Efendi:1989:4 menyatakan dimana bahwa penelitian kualitatif merupakan penelitian dengan pendekatan deskriptif, penelitian deskriptif yang dimaksudkan sebagai pengukuran fenomena sosial tertentu yang mampu mengembangkan konsep serta menghimpun fakta tetapi tidak melakukan hipotesis, sebagaimana hasil wawancara akan digunakan serta dijabarkan sehingga menghasilkan analisis deskriptif sebagaimana dalam penelitian kualitatif.

\section{Teknik Pengumpulan Data}

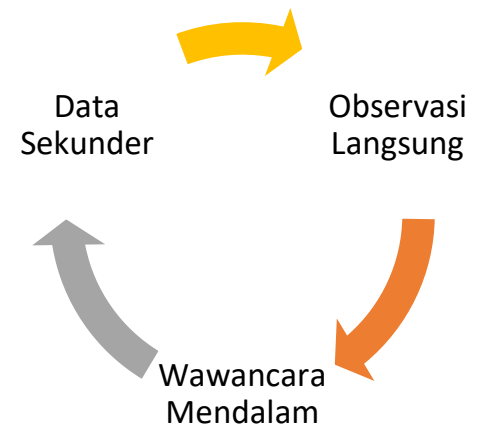

Diagram 2. Teknik Pengumpulan Data 
Teknik pengumpulan data dalam Penelitian ini dilakukan dengan mengumpulkan data primer dan data sekunder. Pengumpulan data yang dilakukan dalam penelitian ini menggunakan teknik-teknik pengumpulan data sebagai berikut:

a). Observasi langsung ke lokasi penelitian pada Desa Tenganan Pegringsingan Kabupaten Karangasem mengenai Jaringan Ekowisata Desa dalam rangka penelusuran data yang tidak diperoleh dalam wawancara, maupun data-data sekunder.

b). Wawancara mendalam (in-depth interview) yang dilakukan terhadap narasumber untuk mengetahui secara persis fenomena-fenomena tentang jaringan ekowisata desa yang ingin diketahui. Data yang akan diperoleh langsung dari informan menjadi sumber data dalam penelitian ini adalah para aktor dalam proses pengembangan Jaringan Ekowisata Desa Tenganan Pegringsingan yaitu:

1. Dari pihak eksekutif, khususnya Kepala Desa Tenganan Pegringsingan, Kelian Adat Desa Tenganan Pegringsingan

2. Pihak masyarakat, yaitu Prajuru adat Desa Tenganan Pegrisingingan, Kabupaten Karangasem, kemudian masyarakat yang dilibatkan sebagai bentuk pemberdayaan dalam sistem Jaringan Ekowisata Desa

3. Pihak swasta, yang bekerjasama dengan pihak Desa dalam pengelolaan JED

c). Data sekunder yang diperoleh dari penelitian ini dihasilkan dalam bentuk laporan tertulis (penelaahan dokumen) serta data yang berasal dari instansi terkait yang akan dijadikan sumber data yang diperoleh dalam bentuk studi pustaka atau literatur, sebagai contoh makalah, artikel, serta berbagai hasil penelitian yang berhubungan dengan masalah atau proses pengembangan Jaringan Ekowisata Desa yang dilakukan peneliti lain, serta menggunakan peraturan perundang-undangan yang relevan yang akan dijadikan acuan dalam mendukung data primer. 


\section{Teknik Penentuan Informan}

Penelitian ini dilakukan di Desa Tenganan Pegringsingan, dan beberapa instansi terkait serta stake holder lainnya yang akan dilakukan berdasarkan purposive sample. Terdapat informan dalam penelitian ini adalah :

Tabel 1. Informan Penelitian

\begin{tabular}{|c|c|c|}
\hline Informan & Alasan & $\begin{array}{c}\text { Teknik pengumpulan } \\
\text { data }\end{array}$ \\
\hline $\begin{array}{c}\text { Kepala Desa } \\
\text { Tenganan } \\
\text { Pegringsingan } \\
\text { yang memiliki kewenangan } \\
\text { dan tanggung jawab dalam } \\
\text { pengembangan Kawasan } \\
\text { objek wisata berbasis JED }\end{array}$ & $\begin{array}{c}\text { Wawancara } \\
\text { (depth interview) }\end{array}$ \\
$\begin{array}{c}\text { Telian adat Desa } \\
\text { Pegringsingan }\end{array}$ & $\begin{array}{c}\text { Sebagai pihak pelaksana dalam } \\
\text { pengembangan sistem JED di } \\
\text { Desa Tenganan Pgringsingan, } \\
\text { Kabupaten Karangasem }\end{array}$ & $\begin{array}{c}\text { Wawancara } \\
\text { (depth interview) dan } \\
\text { data sekunder }\end{array}$ \\
\hline $\begin{array}{c}\text { Masyarakat Adat } \\
\text { atau masyarakat } \\
\text { sekitar obyek wsata }\end{array}$ & $\begin{array}{c}\text { Sebagai pihak yang dilibatkan } \\
\text { dalam pengembangan sistem }\end{array}$ & $\begin{array}{c}\text { Wawancara terstuktur, } \\
\text { observasi, dokumentasi }\end{array}$ \\
\hline Pihak Swasta & $\begin{array}{c}\text { Pihak bekerjasama dengan } \\
\text { Desa Tenganan Pegringsingan }\end{array}$ & $\begin{array}{c}\text { Wawancara } \\
\text { (depth interview) dan } \\
\text { data sekunder }\end{array}$ \\
\hline
\end{tabular}

Penetuan Responden berdasakan atas observasi yang dilakukan dilapangan terdapat beberapa informan yang dapat dirangkum. Teknik penentuan informan yang dilakukan dalam penelitian dengan menggunakan Teknik purposive, dimana Teknik yang ditentukan berdasarkan kriteria yang ditetapkan berdasarkan tujuan penelitian dimana kepala desa Tenganan dipilih dikarenakan informan selaku kepala di lingkungan desa ada Tenganan Pegringsingan yang bertanggung jawab dalam pengelolaan Jaringan Ekowisata Desa, Kelian Adat Desa Tenganan Pegringsingan dipilih 
sebagai informan yang mampu menjawab persoalan dalam partisipasi masyarakat adat. Masyarakat adat tenganan pegringsingan dipilih sebagai informan dalam menginformasikan bentuk dari partisipasi yang sudah dilaksanakan.

\section{Teknik Analisis Data}

Analisis dalam penelitian menggunakan pemahaman intelektual yang dibangun atas dasar pengalaman empiris sebagai langkah-langkah dalam Teknik analisis data diantaranya adalah: 1) Pengumpulan data, 2) Penilaian data, 3) Interprestasi data, 4) Penyimpulan data terhadap hasil interprestasi data, serta 5) analisis data.

\section{PEMBAHASAN}

\section{Perkembangan Pariwisata Desa Adat Tenganan Pegringsingan}

Perkembangan pariwisata di Desa Adat Tenganan Pegringsingan mengubah pola pikir masyarakat setempat, berubahnya pola pikir memberikan inovasi-inovasi baik dalam perkembangan wisata khususnya para pemuda-pemudi, tidak terlepas dari aturan-aturan serta nilai keunikan dari Desa Tenganan yang tetap terjaga sampai saat ini. Melalui kerjasama dari pihak luar yang dimaksudkan adalah Yayasan wisnu, dimana Yayasan wisnu sebagai salah satu Lembaga Swadaya Masyarakat di Bali yang memiliki perhatian khusus dalam pengembangan ekowisata Bali, dalam beberapa proses negosiasi sehingga Yayasan wisnu bersedia menjalin kerjasama dengan kelompok masyarakat Desa Adat Tenganan pegeringsingan dalam mempersiapkan masyarakat agar mampu membuat perencanaan ekowisata sendiri. Dari beberapa proses yang sudah dijalankan diketahui ide-ide muncul sehingga bergeraknya JED lebih digagasi oleh pemuda desa yang sadar akan potensi desa yang dimiliki oleh Desa Adat Tenganan Pegringsingan sebagai desa wisata.

Pengelolaan pariwisata berdasarkan ekowisata yaitu JED Desa Adat Tenganan Pegringsingan memiliki program kerja yang akan di usungkan dan diterapkan kedepannya beberapa rencana yang ingin dikembangakan adalah paket pariwisata Program yang akan diterapkan sudah berjalan bertahap dikarenakan pengelolaannya serta SDM yang masih belum memadai sehingga menjadi kendala dalam penerepana program paket wisatan. Program yang 
ditawarkan bekerjasama dengan pihak UBD yaitu persatuan driver Bali, sehingga memudahkan tamu dalam berkoordinasi serta memudahkan pihak desa dalam proses persiapan jasa paket, jumlah paket dalam satu bulan dapat dihitung berdasarkan penjualan paket oleh pihak driver selaku pihak ketiga dalam mengantar tamu masuk ke Desa Adat Tenganan Pegringsingan. Melalui kerjasama dengan pihak ke tiga baik UBD dan Yayasan wisnu JED sebenarnya memberikan solusi dalam pemberdayaan masyarakt agar lebih mandiri dan mampu memanfaatkan potensi desa yang dimiliki.

Tabel 2. Program Paket Wisata Desa Adat Tenganan Pegringsingan

\begin{tabular}{|l|l|l|}
\hline No & Program & Keterangan Pihak Terkait \\
\hline 1 & Cooking Class & $\begin{array}{l}\text { Ibu-ibu yang dibantu oleh Pemudi Desa Adat } \\
\text { Tenganan Pgeringsingan }\end{array}$ \\
\hline 2 & Trecking & $\begin{array}{l}\text { Pemuda Desa Adat Tenganan dan pihak-pihak } \\
\text { terkait. }\end{array}$ \\
\hline 3 & Tenun, Lontar, dan Melukis & $\begin{array}{l}\text { Masyarakat Tenganan yang ditunjuk langsung } \\
\text { oleh Kepala Desa atas kesepakatan Desa }\end{array}$ \\
\hline
\end{tabular}

Trecking sebagai bentuk perjalanan wisata yang dapat dilakukan dengan berjalan kaki menyusuri Desa Adat Tenganan Pegringsingan aadapun alasan dipilihnya trecking yaitu memberikan keterlibatan secara langsung dalam pengembangan pariwisata Desa Adat Tenganan Pegringsingan, begitu juga dengan menenun, melontar ataupun melukis pada cangkang telur. Keterlibatan meberikan rasa tanggung jawab dan memiliki Desa terlebih untuk masyarakat Tengana sendiri, adapun cooking class dipilih sebagai pemberdayaan ibu-ibu Desa Adat Tenganan dalam berinteraksi langsung dan memperkenalkan makanan khas Bali. Program -program yang dicanangkan memiliki potensi yang besar sebagai peluang dalam pembangunan Desa. 


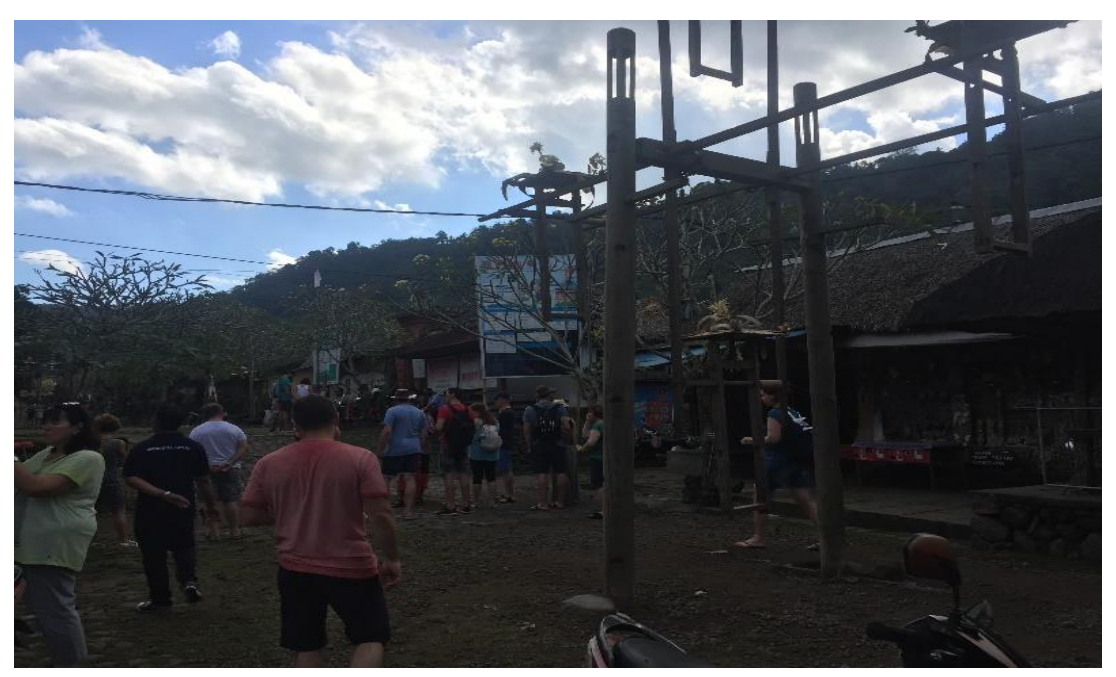

Gambar 1. Wisatawan yang berkunjung di Desa Adat Tenganan Pegringsingan Sumber: Dokumentasi Putri Wirantari 2019

\section{Mata Pencaharian Masyarakat Desa Adat Tenganan Pageringsingan}

Masyarakat desa tenganan mayoritas mata pencariannya yaitu berkebun dan bertani, namun seiring dengan berjalannya waktu adanya pekerjaan sampingan yang dilakukan oleh masyarakat desa Tenganan dalam bidang pengrajin barang seni, pelukis, penulis lontar, pemahat, serta adanya kerajinan dalam industri kain gringsing yang menjadi salah satu daya tarik wisata dalam potensi sektor pariwisata dan potensi budaya yang dimiliki oleh masyarakat desa Tenganan.

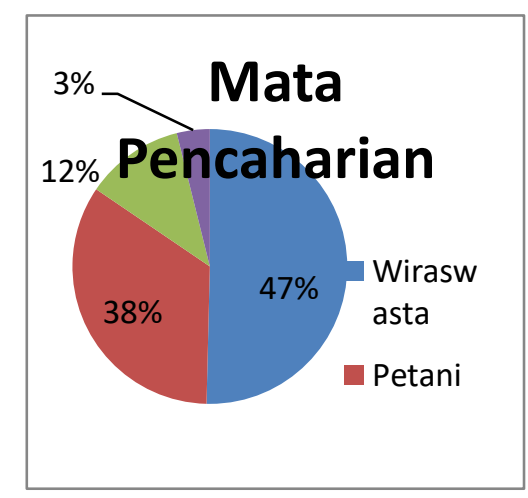

\section{Diagram 3. Penduduk menurut pekerjaan}

Sumber: wawancara Bapak perbekel Desa Adat Tenganan Pengringsingan 
Mata pencaharian masyarakat desa adat Tenganan sangat beragam, Pada jaman dahulu kebanyakan masyarakat memilih pekerjaan sebagai petani atau berkebun, namun dengan banyaknya wisatwan yang berkunjung ke desa adat Tenganan Pegringsingan maka masyarakat Tenganan Pegringsingan melakukan pekerjaan sampingan menjadi perajin sebanyak $12 \%$ dan wiraswasta sebanyak 47\% yang memiliki artshop dan menjual di sekitar desa ataupun diluar desa adat Tenganan Pegringsingan mata pencarian yang paling sedikit adalah pegawai sebanyak $3 \%$. Kebanyakan masyarakat Tenganan pegringsingan memiliki keterampilan dalam memahat, melukis, dan membuat kain tenun geringsing yaitu kain tenun khas Desa Adat Tenganan Pegringsingan . Mata pencaharian masyarakat Desa Adat Tenganan Pegrisingan tidak melupakan pekerjaan utamanya dalam mengelola sawah dan kebun yang dimiliki dikarenakan sawah dan kebun adalah hal yang wajib dilakukan sebagai warisan budaya yang sudah dilakukan secara turuntemurun masyarakat yang dengan rentang usia 15-30 an tahun biasanya memanfaatkan potensi wisata yang dimiliki, beberapa anak muda di Desa Adat Tenganan Pegeringsingan mengambil pekerjaan melukis kulit telur, memahat, ukurin patung, melontar dan menenun sudah genjar dilakukan.

\section{Pengelolaan Keuangan Desa Adat Tenganan Pegringsingan}

Pengelolaan keuangan desa menjadi hak dan kewajiban Desa dalam penyelenggaraan pemerintahan desa yang dinilai bahwa uang tersebut termasuk didalamnya sebagai bentuk kekayaan lain yang berhubungan dengan hak dan kewajiban desa dalam pengelolaan Apdes. Pengelolaan keuangan dilakukan oleh bendahara desa dan perangkat desa yang bertanggungjawab kepada kepala desa dalam mebantu kepala desa sebagai penyelenggaraan pemerintah desa. Semua transaksi keuangan desa serta pengelolaanya dilaksanakan melalui kas desa. Dari programprogram yang sudah berjalan seperti maka keuangan dikembalikan kedesa dan akan dikelola untuk kepentingan masyarakat Desa Adat Tenganan Pegeringsingan kembali misalkan saja masyarakat akan diberikan beras masing-masing kepala diantaranya: 


\section{Hak Perbulan Masyarakat Desa Adat \\ Tenganan Pegeringsingan}

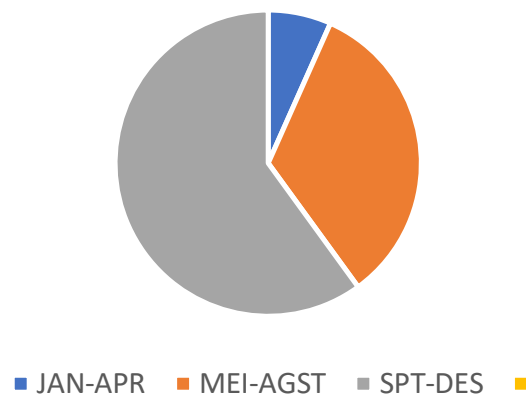

\section{Diagram 4. Hak Perbulan Masyarakat Desa Adat Tenganan Pegringsingan}

Penghasilan dari paket wisata memberikan banyak hal yang bermanfaat dan mampu meningkatkan peluang kerja bagi masyarakat dan membangun fasilitas-fasilitas sebagai pendukung pengembangan pariwisata, yang tidak merubah bangunan yang sudah ada. Sebagaimana diketahui bangunan dapat direhab namun tidak dapat merubah bangunan yang terdahulu sebagai warisan kebudayaan, biasanya dana yang sudah ada lebih banyak merehab fasiltas umum diantaranya bangunan suci, bale perembugan, dan jalan-jalan yang sudah rusak selebihnya dikembalikan ke masyarakat yang diberikan sebagai hak perbulan dimana dalam bulan pertama dengan rentang bulan Januari sampai April masyarakat diberikan $1 \mathrm{~kg}$ beras setiap KK, untuk bulan kedua dengan rentang bulan Mei sampai Agustus diberikan 50 kg berasa serta di bulan ke tiga September sampai Desember diberikan $200 \mathrm{~kg}$ dalam 1 natah. Pengelolaan dana desa di desa menjadi aspek penting dan mendasar yang harus dimiliki oleh para pemangku kepentingan di level pemerintah desa, khususnya perangkat desa, dalam mewujudkan transparansi dan akuntabilitas keuangan desa Tenganan Pegringsingan.

\section{Peran Masyarakat Desa Adat Tenganan Pegringsingan Dalam Pengembangan Pariwisata}

Pengembangan program ekowisata memiliki kriteria-kriteria ekowisata yang telah dirumuskan dalam lokakarya ekowisata Bali, dapat dijabarkan sebagai berikut : a. Memproritaskan Sumber Daya Manusia sesuai dengan kehalian terutama Sumber Daya Manusia Lokal, b. Pembangunan oprasional yang sesuai dengan tata krama, kearifan lokal, c. Tidak menggangu aktivitas keagamaan masyarakat lokal setempat, d. Mentaati awig-awig desa setempat, e. 
berkonsep Tri Hita Karana. Model pengembangan pariwisata di Desa Tenganan Pegringsingan termasuk model kepariwisataan berskala kecil, dengan pengembangan masyarakat lokal program JED memberikan peluang ekonomi pada masyarakat setempat, baik dalam pengelolaan Sumber Daya Manusia, ataupun dalam segi ekonomi dengan membuka usaha-usaha kecil di lingkungan Desa Tenganan Pegringsingan. Masyarakat sangat berperan penting dalam pengelolaan Program JED sebagai pengembangan Kawasan berbasis lokal wisdom. Sebagai upaya peningkatan kemampuan serta pengetahuan dalam pengembangan pariwisata program JED masyarakaat lokal di Desa Tenganan Pegringsingan terdapat beberapa Teknik pelatihan yang bisa diterapkan yang berkaitan dengan peningkatan serta pengelolaan Sumber Daya Manusia diantaranya adalah :

Tabel 3. Program Peningkatan Sumber Daya Manusia

\begin{tabular}{|l|l|}
\hline \multicolumn{1}{|c|}{ No } & \multicolumn{1}{|c|}{ Program } \\
\hline 1 & Teknik Memandu Wisatawan \\
\hline 2 & $\begin{array}{l}\text { Pengetahuan mengenai asset dan potensi wiasata di Desa Tenganan } \\
\text { Pegringsingan }\end{array}$ \\
\hline 3 & $\begin{array}{l}\text { Norma- Norma dan peraturan dalam pengemabangan budaya di Desa } \\
\text { Tenganan Pegringsingan }\end{array}$ \\
\hline
\end{tabular}

\section{Peran Pihak Eksternal Dalam Penerapan Program JED}

Penerapan program JED di Desa Adat Tenganan sebagai program penguat dalam masalah keletarian lingkungan terutama dalam bidang ekowisata Desa sebagai bentuk kesadaran maka kelompok masyarakat Tenganan menghubungi Yayasan Wisnu sebagai LSM yang berfokuskan kepada masalah kelestarian lingkungan yang dilaksanakan pada awal tahun 1998, dengan memiliki tujuan utama Yayasan wisnu terpampang jelas yaitu pembentukan pariwisata berdasarkan atas program ekowisata dalam memperkuat perlindungan terhadap local wisdom, dengan terfokus terhadap nilai tradisi dan kepentingan masyarakat desa adat Tengannan sehingga tidak tergeserkan oleh kepentingan pariwisata yang bersifat komersil berskala besar, dengan pengembangan program ekowisata desa tidak menghilangkan potensi ataupun merusaka potensi yang sudah ada,

Pengembangan program ekowisata yang telah disampaikan oleh pegiat Yayasan wisnu, memandang bahwa perencanaan yang melibatkan partisipasi masyarakat untuk memperoleh 
konsep dan pola pengelolaan daerah wisata yang tepat dengan mengingat bahwa kawasa Tenganan mempunyai potensi budaya tradisional yang dipegang kukuh sampai saat ini, serta adanya Sumber Daya Hayati yang sangat besar, namun dalam proses pengembangan potensi alam serta budaya masyarakat Tenganan masih belum bisa mengelola dengan baik, seiring dengan berjalannya waktu arus investasu dari pihak ke tiga sangat besar dan tidak mampu ditangani dengan baik sehingga konsep dari Yayasan wisnu bermula dengan cara Sangkepan yang melibatkan masyarakat desa Tenganan Pegringsingan, adapun bagan dapat digambarkan sebagai berikut:

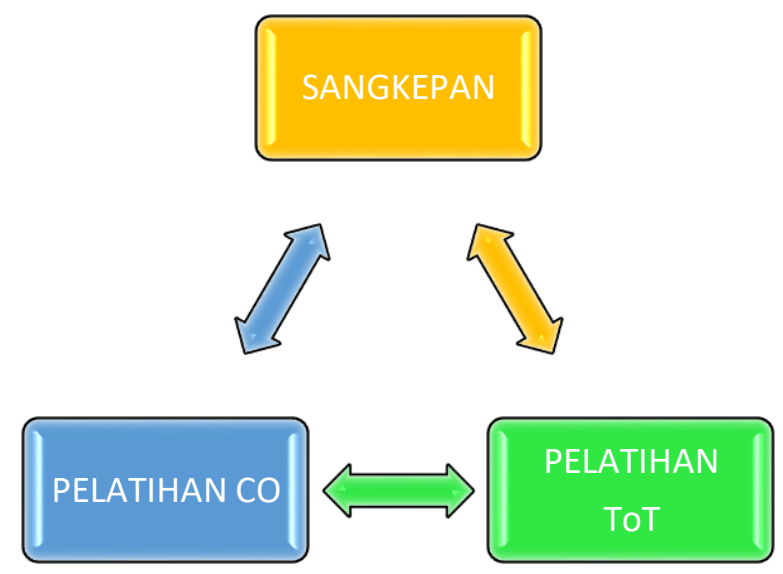

\section{Diagram 4. Konsep Yayasan Wisnu}

\section{A. Sangkepan}

Pesangakepan dalam partispipasi masyarakat dengan Yayasan wisnu sebagai salah satu konsep yang memiliki tujuan dalam menyamakan persepsi serta konsep ataupun programprogram yang berkaitan dengan ekowisata di Tenganan Pegringsingan, Yayasan wisnu melakukan sosialisasi dengan cara sangkep dengan mengabungkan secara keseluruhan masyarakat Tenganan dengan sangkep bertahap, sangkep dilakukan mempertemukan perwakilan dan mensosialisasikan program serta merancang program ekowisata yang dilakukan selama 3 bulan yang menghasilkan pengelolaan ekowisata berupa penguatan dan menerima kerjsama dengan pihak lain diantaranya UBD (United Bali Driver). 


\section{B. Pelatihan ToT}

Pelatihan ToT memiliki tujuan dimana para peserta harus dibekali keterampilan khusus dalam memfasilitasi suatu program yang akan diterapkan, dengan mengetahui keterampilan masyarakat, pelatihan ToT juga mengarahkan masyarakat untuk turut aktif dalam menemukan dan merumuskan masalah yang terdapat di desa terkait dengan potensi desa, sasaran pelatihan oleh Yayasan wisnu yaitu menyasar kepada masyarakat yang berdagang anyaman, tenun, lukisan telur, lontar dan lain sebagainya serta masyarakat lainnya yang memiliki edukasi terkait dengan pariwisata juga terlibat dalam pengelolaan potensi alam dan bekerja sama dengan UBD.

\section{Pelatihan CO}

Terkait dengan pelatihan CO (community organizing), Yayasan wisnu menyasar komuniti yang ada di desa Tenganan sebagai bentuk pengumpulan pihak-pihak terlibat yang memiliki kepentingan terkait dengan pengelolaan potensi budaya, ptensi SDM, serta potensi alam yang dimiliki di desa Tenganan. Promosi di desa Tenganan yang menjadi kelemahan yang tidak dikelola dengan baik, berdasarkan atas pantauan dari Yayasan wisnu bahwa desa Tenganan sering berfokus pada kegiatan ritual keagaaman sehingga dimanfaatkan oleh Yayasan wisnu untuk mempromosikan kepada wisatawan terkait dengan kegiatan yang dilakukan, namun seiring berjalannnya waktu seringkali ketika desa Tenganan tidak ada kegiatan ritual wisawatan hanya diajak berkeliling desa dan tidak ada kegiatan lainnya sehingga adanya perubahan midset untuk menarik perhatian wisatawan dengan melakukan pelatihan CO memfokuskan kepada komuniti seperti pedagang kerajinan, guide, biro perjalanan, pemerintah desa adat, pemerintah daerah dalam pemanfaatan alam sebagai daya tarik wisatawan, sehingga melalui pemikiran serta kesepakatan masyarakat pelaihan CO menghasilkan paket wisata yang di promosikan kepada wisatawan tanpa mengurangi dan mengubah potensi budaya serta potensi alam yang dimiliki oleh desa Tenganan Pegringsingan.

\section{KESIMPULAN}

Berdasarkan penelitian diatas maka penelitian Peran Desa Adat Tenganan Pegringsingan Dalam Pengelolaan Keuangan Desa Melalui Jaringan Ekowisata Desa (JED) dapat disimpulkan sebagai berikut : 
a. Pengembangan pariwisata dalam peningkatan ekonomi daerah sangat penting dilakukan, terkait dengan program Ekowisata Desa. Desa Tenganan Pegringsingan menerapkan program JED sebagai pengembangan Pariwisata di Desa Tenganan Pegringsingan.

b. Pengelolaan Keuangan setiap tahunnya Rp 350.000.000 juta dari hasil pengelolaan pariwisata yang dikelola kembali oleh Desa Tenganan Pegringsingan.

c. Pengelolaan Sumber Daya Manusia memproritaskan masyarakat lokal Desa Tenganan Pegringsingan.

d. Model pengembangan pariwisata menggunakan interaksi langsung untuk memudahkan interaksi dengan wisatawan

e. Pengelolaan keuangan dilakukan oleh bendahara desa dan perangkat desa yang bertanggungjawab kepada kepala desa dalam membantu kepala desa sebagai penyelenggaraan pemerintah desa. 


\section{DAFTAR PUSTAKA}

Bastian, Indra. (2005). Akuntansi Sektor Publik. Jakarta: Erlangga.

Brannen, Yilia. (1997). Memadu Metode Penelitian Kualitatif dan Kuantitatif. Yogyakarta : Pustaka Pelajar

Hadinoto, K. (1996). Perencanaan Pembangunan Destinasi Priwisata. Jakarta: Universitas Indonesia

Kusumasari, Bevaola, dkk. (2015). Memahami Model Bisnis Organisasi Sosial di Indonesia. Yogyakarta: Gava Media

Laksono, Dandhy. (2016). Desa Sosialis bernama Tenganan. www.pojoksamber.com (Diakses pada 18 April 2016)

Marpaung, Happy. (2000). Pengetahuan Kepariwisataan. Bandung : Alfa-Beta

Noor, Juliansyah. (2011). Metodologi Penelitian. Jakarta: Kencana Prenadamedia Group.

Paturisi, Samsul Alam. (2002). Perencanaan Tata Ruang Kawasan Pariwisata. Denpasar: UNUD.

Prawirosentono, Suyadi. (1999). Manajemen Sumber Daya Manusia (Kebijakan Kinerja Karyawan), Kiat Membangun Organisasi Kompetitif Menjelang Perdagangan Bebas Dunia. Edisi Pertama. Yogyakarta: BPFE.

Satori, Djam'an \& Aan Komariah. (2014). Metodologi Penelitian Kualitatif. Bandung: Alfabeta

Sjafrizal. (2014). Perencanaan Pembangunan Daerah Dalam Era Otonomi. Jakarta: PT Rajagrafindo Persada.

Sugiyono. (2014). Metode Penelitian Kuantitatif, Kualitatif, dan R\&D. Bandung: Alfabeta.

Sukarsa. (1999). Pengantar Pariwisata. Ujung Pandang: BKS-PTN-INTIM.

Sunaryo, Bambang. (2013). Kebijakan pembangunan destinasi pariwisata, konsep dan aplikasinya di Indonesia.Yogyakarta:Gava media

Suyitno. (2001). Perencanaan Wisata. Yogyakarta: Kasinius.

Yoeti. Oka. A. (2000). Ekowisata Berwawasan Lingkungan Hidup. Jakarta : PT. Pitja. 